\title{
KARAKTERISTIK FISIKOKIMIA DAN FUNGSIONAL PATI HIDROTERMAL UBI JALAR UNGU
}

\author{
[Physicochemical and Functional Characteristics of Hydrothermal \\ Purple Sweet Potato Starch]
}

\author{
Firstyarikha Habibah $^{1)}$, Sedarnawati Yasni ${ }^{1) \star}$ dan Sri Yuliani ${ }^{2)}$ \\ 1) Departemen Ilmu dan Teknologi Pangan, Fakultas Teknologi Pertanian, Institut Pertanian Bogor, Bogor \\ 2) Balai Besar Penelitian dan Pengembangan Pasca Panen Pertanian, Bogor
}

Diterima 30 Januari 2018 / Disetujui 27 April 2018

\begin{abstract}
Starch from sweet potato is widely used in foods product. However, in general native sweet potato starch has constrains that often inhibits its application in food products and hydrothermal modification might overcome the problem. This study aimed to study the effect of hydrothermal treatment on the physicochemical and functional characteristics of purple sweet potato starch. The study was conducted in two stages, i.e. modification of starch of purple sweet potato variety antin-3 hydrothermally, i.e. using moisture content of $30,50 \%$ and heating temperature of 55 and $75^{\circ} \mathrm{C}$, and characterization of the physicochemical and functional properties of the modified starch. The yield of starch from purple sweet potato by wet extraction method was $16.81 \pm 1.48 \%$. The hydrothermal treatment on the purple sweet potato starch did not alter the concentration of starch, amylose and amylopectin. The natural and hydrothermal starches had polygonal granular shape. The swelling power of the hydrothermal starch incubated at $75^{\circ} \mathrm{C}$ was higher than that incubated at $55^{\circ} \mathrm{C}$, while the solubility of the hydrothermal starch was lower than the natural starch. The natural and hydrothermal starches of purple sweet potato had an A-type starch gelatinization profile. Hydrothermal treatment of starch with $50 \%$ moisture content at $75^{\circ} \mathrm{C}$ could change the functional properties of starch, i.e increased the proportion of slowly digestible starch by $22 \%$.
\end{abstract}

Keywords: functional, hydrothermal, physicochemical, purple sweet potato, starch modification

\begin{abstract}
ABSTRAK
Pati merupakan salah satu alternatif bentuk olahan ubi jalar menjadi bahan pangan yang bisa diaplikasikan secara luas dan tidak mudah rusak. Namun, secara umum pati alami ubi jalar mempunyai kekurangan yang sering menghambat aplikasinya pada produk pangan, sehingga perlu dimodifikasi, yaitu melalui teknik modifikasi fisik seperti hidrotermal. Penelitian ini bertujuan untuk mempelajari pengaruh perlakuan hidrotermal terhadap karakteristik fisikokimia dan fungsional pati ubi jalar ungu. Penelitian dilakukan dalam dua tahapan yaitu tahap modifikasi pati ubi jalar ungu varietas antin-3 secara hidrotermal dengan variasi kadar air (30 dan 50\%) dan suhu $\left(55\right.$ dan $75^{\circ} \mathrm{C}$ ) serta tahap karakterisasi fisikokimia dan fungsional pati hasil modifikasi. Pati diekstraksi dengan cara basah menghasilkan rendemen sebanyak 16,81 $\pm 1,48 \%$. Perlakuan hidrotermal pada pati ubi jalar ungu tidak mengubah kadar pati, amilosa dan amilopektin. Morfologi pati alami dan pati hidrotermal mempunyai bentuk granula yang sama yaitu poligonal. Daya kembang pati hidrotermal yang diinkubasi pada suhu $75^{\circ} \mathrm{C}$ lebih tinggi daripada yang diinkubasi suhu $55^{\circ} \mathrm{C}$, sementara kelarutan pati hidrotermal lebih rendah daripada pati alami. Pati alami dan pati hidrotermal ubi jalar ungu memiliki profil gelatinisasi pati tipe A. Perlakuan hidrotermal dengan kadar air $50 \%$ dan suhu $75^{\circ} \mathrm{C}$ mampu mengubah sifat fungsional pati yaitu meningkatkan fraksi pati lambat cerna sebesar $22 \%$.
\end{abstract}

Kata kunci: fisikokimia, fungsional, hidrotermal, modifikasi pati, ubi jalar ungu

\section{PENDAHULUAN}

Ubi jalar sebagai bagian dari kekayaan hayati Indonesia merupakan bahan pangan lokal yang perlu ditingkatkan pemanfaatannya. Kurangnya informasi mengenai bentuk olahan ubi jalar dan belum

*Penulis Korespondensi:

Email: sedarnawati@yahoo.com berkembangnya industri pengolahan komoditas ini sebagai bahan baku pangan menyebabkan permintaan terhadap ubi jalar relatif rendah. Selain itu, ubi jalar merupakan bahan pangan yang tidak dapat disimpan dalam jangka waktu lama. Hal ini berdampak pada melimpahnya produksi dan merosotnya harga ubi jalar pada saat panen raya (Ginting et al., 2014). Balai Penelitian Kacang-kacangan dan Umbiumbian (Balitkabi) Malang telah mengembangkan 
berbagai varietas ubi jalar ungu, salah satunya adalah antin-3. Ubi jalar ini memiliki potensi hasil umbi yang cukup besar yaitu 30,6 ton/ha. Namun demikian, ubi jalar ini belum dimanfaatkan secara optimal. Oleh karena itu diperlukan alternatif pengolahan ubi jalar menjadi bahan pangan yang tidak mudah rusak dan bisa diaplikasikan secara luas, yaitu dalam bentuk pati.

Pati merupakan salah satu komponen nutrisi yang penting dalam pangan serta bisa menjadi penentu karakteristik produk pangan (Syamsir et al., 2012). Namun, secara umum pati alami mempunyai kekurangan yang sering menghambat aplikasinya pada produk pangan, sehingga pati perlu dimodifikasi terlebih dahulu. Salah satunya melalui teknik modifikasi fisik seperti hidrotermal, yang memodifikasi sifat fisikokimia pati tanpa merusak struktur granulanya (Zavareze dan Dias, 2011). Selain itu perlakuan hidrotermal juga mampu meningkatkan fungsionalitas pati, yaitu meningkatkan fraksi pati lambat cerna. Menurut Trinh et al. (2012), makanan yang mengandung pati lambat cerna dapat mencegah peningkatan secara cepat glukosa darah dan memberikan pasokan glukosa yang berkelanjutan sehingga dapat mencegah terjadinya diabetes. Perlakuan hidrotermal terhadap pati ubi jalar ungu varietas ayamurasaki yang dilakukan oleh Agustinisari (2011) dengan kadar air $50 \%$ dan suhu pemanasan $75^{\circ} \mathrm{C}$ dapat meningkatkan kadar fraksi lambat cerna hingga $50 \%$ dari pati alaminya, serta mempunyai profil pasta pati yang stabil selama pemanasan, pengadukan serta pendinginan dan mampu menurunkan kadar glukosa darah tikus diabetes sebesar 61,64\%.

Penelitian ini bertujuan untuk mempelajari pengaruh perlakuan hidrotermal terhadap karakteristik fisikokimia dan fungsional pati lambat cerna ubi jalar ungu varietas antin-3, yang diduga akan memberikan hasil yang berbeda dari perlakuan hidrotermal terhadap ubi jalar ungu varietas ayamurasaki. Menurut Jusuf et al. (2013) kadar pati dari ubi jalar ungu segar varietas ayamurasaki lebih tinggi daripada antin-3 yaitu 19,61 dan 13,35 (\% bb).

\section{BAHAN DAN METODE}

\section{Bahan}

Bahan yang digunakan dalam penelitian ini antara lain bahan utama ubi jalar ungu varietas Antin-3 berumur 4,5 bulan yang diperoleh dari Balai Penelitian Kacang-kacangan dan umbi-umbian, Malang, Jawa Timur.

\section{Metode}

Penelitian dilakukan dalam dua tahapan yaitu (1) modifikasi pati ubi jalar ungu varietas antin-3 secara hidrotermal, dan (2) karakterisasi fisikokimia dan fungsional pati hasil modifikasi. Ekstraksi pati di- lakukan dengan metode ekstraksi basah. Ubi jalar ungu antin-3 disortasi, dicuci, dikupas kemudian diparut dan dilakukan penambahan air 1:10. Setelah itu dilakukan penyaringan bertingkat 100 mesh. Pati dikeringkan di dalam oven (Memmert, Germany) pada suhu $50^{\circ} \mathrm{C}$ sampai kadar air $\pm 10 \%$. Selanjutnya dilakukan modifikasi pati secara hidrotermal dengan metode yang dikembangkan oleh Agustinisari (2011). Kadar air pati ubi jalar ungu dikondisikan menjadi 30 dan $50 \%$ dengan penambahan air distilasi dan dikemas rapat dalam kontainer lalu disimpan pada suhu kamar selama 24 jam untuk mencapai kesetimbangan. Kemudian dipanaskan dalam oven selama 24 jam pada suhu 55 dan $75^{\circ} \mathrm{C}$. Inkubasi pada suhu tersebut tidak mengeringkan sampel pati, oleh karena itu dilanjutkan dengan pengeringan pati menggunakan oven pada suhu $30-40^{\circ} \mathrm{C}$ selama semalam. Sampel pati tersebut selanjutnya dihaluskan hingga 100 mesh.

\section{Prosedur analisis}

Tahapan analisis dimulai dengan analisis sifat kimia pati hidrotermal ubi jalar ungu yang meliputi analisis amilosa dan total pati (Andarwulan, 2011). Kemudian analisis sifat fisik pati meliputi analisis morfologi dan sifat birefringence granula pati yang dilakukan menggunakan mikroskop polarisasi cahaya (Olympus Optical Co. Ltd, Japan), daya kembang (swelling power) dan kelarutan pati (Kong et al., 2016) juga profil gelatinisasi pati dengan menggunakan Rapid Visco Analysis (RVA). Analisis sifat fungsional mencakup analisis fraksi pati (Brumovsky dan Thompson, 2001). Profil gelatinisasi pati alami dan pati hidrotermal ubi jalar ungu dianalisis menggunakan RVA. Sebanyak $\pm 3,0 \mathrm{~g}$ sampel (berat kering) ditimbang dalam wadah RVA, lalu ditambahkan $\pm 25 \mathrm{~g}$ akuades. Pengukuran dengan RVA mencakup fase proses pemanasan dan pendinginan pada pengadukan konstan (160 rpm). Pada fase pemanasan, suspensi pati dipanaskan dari suhu 50 hingga $95^{\circ} \mathrm{C}$ dengan kecepatan $6^{\circ} \mathrm{C} /$ menit, kemudian dipertahankan pada suhu tersebut selama 5 menit. Setelah fase pemanasan selesai, dilanjutkan dengan fase pendinginan, yaitu suhu diturunkan dari 95 menjadi $50^{\circ} \mathrm{C}$ dengan kecepatan $6^{\circ} \mathrm{C} /$ menit, lalu dipertahankan pada suhu tersebut selama 2 menit. Instrumen RVA memplot kurva profil gelatinisasi sebagai hubungan dari nilai viskositas (cP) pada sumbu y dengan perubahan suhu $\left({ }^{\circ} \mathrm{C}\right)$ selama fase pemanasan dan pendinginan pada sumbu $\mathrm{x}$.

Analisis fraksi pati cepat cerna, lambat cerna dan tahan cerna dilakukan dengan menggunakan metode Brumovsky dan Thompson (2001) dengan sedikit modifikasi. Pankreatin (Sigma P-1750) sebanyak $9 \mathrm{~g}$ ditambah dengan $9 \mathrm{~mL}$ akuades dalam gelas piala pyrex $50 \mathrm{~mL}$ kemudian diaduk menggunakan magnetic stirrer selama 10 menit. Suspensi ini kemudian disentrifus pada $1500 x$ g selama 10 
menit. Supernatan yang diperoleh dipindahkan ke dalam labu ukur pyrex $100 \mathrm{~mL}$ bertutup yang berisi 2,65 mL larutan amiloglukosidase (Sigma A-9913) dan ditepatkan dengan akuades. Sampel pati ditimbang $500 \mathrm{mg}$ (basis basah), kemudian ditempatkan dalam erlenmeyer pyrex $50 \mathrm{~mL}$. Selanjutnya ditambahkan $15 \mathrm{~mL}$ buffer sodium asetat $(\mathrm{pH} \mathrm{5,2)} \mathrm{dan} 5$ buah kelereng. Erlenmeyer tersebut diletakkan dalam shaker waterbath $35^{\circ} \mathrm{C}$ dengan kecepatan 150 rpm selama 10 menit. Larutan enzim (10 mL) ditambahkan ke dalam setiap erlenmeyer, kemudian dikocok kembali. Setelah 20 menit, $1 \mathrm{~mL}$ larutan sampel diambil untuk dianalisa kadar glukosanya. Glukosa yang terukur pada 20 menit pertama disebut Rapid Available Glucose (RAG) yang bila dikalikan dengan faktor konversi 0,9 dapat disebut sebagai Rapidly Digestible Starch (RDS). Kadar Slowly Digestible Starch (SDS) diketahui dari hasil pengukuran kadar glukosa sampel setelah inkubasi selama 120 menit. Analisis glukosa dilakukan menggunakan DNS (Miller, 1959). Sampel yang masih tersisa dianalisis total patinya dengan cara dididihkan dalam alat pemasak selama 30 menit, kemudian didinginkan dalam es selama 10 menit. Selanjutnya ditambahkan $\mathrm{KOH}$ (Merck, Germany) $7 \mathrm{M}$ sebanyak $10 \mathrm{~mL}$. Campuran ini diaduk selama 30 menit. Setelah itu diambil sebanyak $200 \mu \mathrm{L}$ untuk ditambahkan ke dalam tabung yang berisi $1 \mathrm{~mL}$ asam asetat (Merck, Germany). Sebanyak $40 \mu \mathrm{L}$ larutan amiloglukosidase (dilarutkan dalam akuades 1:5,25 dari larutan AMG asal) ditambahkan ke dalam tabung reaksi tersebut. Tabung diinkubasi pada $70^{\circ} \mathrm{C}$ selama 30 menit. Kadar glukosa diketahui dengan mereaksikan 3 $\mathrm{mL}$ larutan sampel dengan $3 \mathrm{~mL}$ pereaksi DNS (Merck, Germany) kemudian dipanaskan $100^{\circ} \mathrm{C}$ selama 15 menit, ditambah $1 \mathrm{~mL}$ rochelle salt, didinginkan dan diukur absorbansinya pada panjang gelombang $575 \mathrm{~nm}$ menggunakan spektrofotometer UV-Vis (UV min 1240, Shimadzu, Japan).

\section{Rancangan penelitian dan analisis statistik}

Rancangan percobaan yang digunakan dalam penelitian ini adalah rancangan acak lengkap. Hasil analisis karakterisasi fisikokimia dan fungsional diolah menggunakan SPSS dengan metode analisis one way ANOVA yang dilanjutkan dengan uji Duncan jika berbeda nyata dengan taraf kepercayaan $95 \%$.

\section{HASIL DAN PEMBAHASAN}

\section{Rendemen ekstrak ubi jalar ungu}

Proses ekstraksi basah pada ubi jalar ungu varietas antin-3 menghasilkan rendemen pati ubi

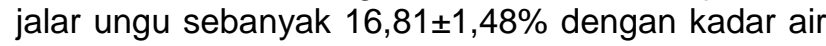
$9,45 \pm 0,02 \%$. Besaran rendemen pati ubi jalar sekitar
$15-25 \%$ dimana besarnya rendemen ini dipengaruhi oleh sifat genetik varietas, umur panen dan juga lingkungan tumbuh (Rahayuningsih et al., 2012). Penelitian yang dilakukan oleh Ginting et al. (2005) mengenai karakteristik pati beberapa ubi jalar yang ditanam oleh petani di sekitar Malang yang salah satunya adalah ubi jalar ungu varietas ayamurasaki dengan umur panen 4,5 bulan menghasilkan rendemen pati sebesar $14,2 \%$.

\section{Karakteristik kimia pati ubi jalar ungu}

Hasil analisis kadar pati, amilosa dan amilopektin pati alami ubi jalar ungu antin-3 dan pati yang telah dimodifikasi secara hidrotermal ditunjukkan pada Tabel 1.

Kadar pati sangat nyata dipengaruhi oleh varietas ubi jalar yang digunakan (Nazhrah, 2014). Selain itu dipengaruhi juga oleh cara ekstraksi, sehingga adanya ikutan senyawa lain seperti protein, lemak, serat dan abu akan menentukan tingkat kemurnian pati. Amilosa dan amilopektin merupakan polisakarida utama penyusun pati. Proporsi amilosa dan amilopektin pati bervariasi, umumnya sekitar 20:80 (Polnaya et al., 2015). Hal ini dapat dipengaruhi oleh varietas, umur panen, iklim dan jenis tanah. Kadar amilosa memengaruhi tingkat kemudahan pembentukan gel. Pati dengan kadar amilosa rendah jika dibuat pasta akan bersifat lunak dan relatif tidak membentuk gel yang kokoh (Interpares et al., 2015).

Peningkatan suhu pada proses hidrotermal cenderung menurunkan kadar amilosa pati. Walaupun demikian hasil analisis sidik ragam menunjukkan bahwa penurunan kadar amilosa tersebut tidak berbeda nyata. Peningkatan kadar amilosa pada perlakuan hidrotermal suhu $55^{\circ} \mathrm{C}$ terjadi karena pemanasan dilakukan pada suhu yang lebih rendah dari suhu gelatinisasi dimana suhu gelatinisasi ini dapat diketahui melalui analisis karakteristik profil gelatinisasi pati menggunakan rapid visco analyzer (RVA) yang terlihat pada Tabel 2. Dari tabel tersebut diketahui bahwa pati alami ubi jalar ungu mulai mengalami gelatinisasi pada suhu $74,55^{\circ} \mathrm{C}$. Menurut Miao et al. (2010), energi yang diserap granula selama pemanasan pada suhu yang lebih rendah dari suhu gelatinisasinya akan membuka lipatan heliks ganda amilopektin dan juga memfasilitasi pengaturan atau pembentukan ikatan-ikatan baru antar molekul. Dalam hal ini dimungkinkan terjadi perubahan amilopektin menjadi amilosa sehingga kadar amilosa pati hidrotermal suhu $55^{\circ} \mathrm{C}$ lebih tinggi dibandingkan pati alaminya, seperti yang diungkapkan oleh Luna et al. (2015) dan Shariffa et al. (2017) bahwa peningkatan kadar amilosa setelah perlakuan pemanasan merupakan indikasi terjadinya pemecahan struktur amilopektin. 
Tabel 1. Kadar pati, amilosa dan amilopektin pati alami dan pati hidrotermal ubi jalar ungu antin-3

\begin{tabular}{lccccc}
\hline \multicolumn{1}{c}{ Parameter } & \multirow{2}{*}{ Pati Alami } & $\begin{array}{c}\text { Pati Hidrotermal } \\
30 \%-55^{\circ} \mathrm{C}\end{array}$ & $\begin{array}{c}\text { Pati Hidrotermal } \\
30 \%-75^{\circ} \mathrm{C}\end{array}$ & $\begin{array}{c}\text { Pati Hidrotermal } \\
50 \%-55^{\circ} \mathrm{C}\end{array}$ & $\begin{array}{c}\text { Pati Hidrotermal } \\
50 \%-55^{\circ} \mathrm{C}\end{array}$ \\
\hline Kadar pati (\%) & $91,11 \pm 2,80^{\mathrm{a}}$ & $83,28 \pm 2,53^{\mathrm{a}}$ & $88,02 \pm 5,27^{\mathrm{a}}$ & $83,98 \pm 3,06^{\mathrm{a}}$ & $87,42 \pm 1,35^{\mathrm{a}}$ \\
Kadar amilosa (\%) & $44,00 \pm 0,23^{\mathrm{a}}$ & $44,18 \pm 0,85^{\mathrm{a}}$ & $43,78 \pm 0,56^{\mathrm{a}}$ & $45,22 \pm 2,62^{\mathrm{a}}$ & $43,02 \pm 0,11^{\mathrm{a}}$ \\
Kadar amilopektin (\%) & $47,11 \pm 2,57^{\mathrm{a}}$ & $39,10 \pm 1,68^{\mathrm{a}}$ & $44,24 \pm 4,71^{\mathrm{a}}$ & $38,76 \pm 0,44^{\mathrm{a}}$ & $44,40 \pm 1,24^{\mathrm{a}}$ \\
\hline
\end{tabular}

Tabel 2. Profil gelatinisasi pati alami dan pati hidrotermal ubi jalar ungu antin-3 hasil pengukuran dengan RVA

\begin{tabular}{|c|c|c|c|c|c|}
\hline \multirow{2}{*}{ Parameter } & \multicolumn{5}{|c|}{ Nilai } \\
\hline & Pati Alami & $30 \%, 55^{\circ} \mathrm{C}$ & $30 \%, 75^{\circ} \mathrm{C}$ & $50 \%, 55^{\circ} \mathrm{C}$ & $50 \%, 75^{\circ} \mathrm{C}$ \\
\hline Suhu awal gelatinisasi $\left({ }^{\circ} \mathrm{C}\right)$ & 74,9 & 74,55 & 75,75 & 74,9 & 77,75 \\
\hline Viskositas maksimum (cP) & 6351 & 7015 & 5523 & 7119 & 6638 \\
\hline Viskositas pada $95^{\circ} \mathrm{C}(\mathrm{cP})$ & 3969 & 4434 & 4332 & 4530 & 5236 \\
\hline Viskositas breakdown (cP) & 4061 & 4528 & 3049 & 4630 & 3666 \\
\hline Viskositas pada $50^{\circ} \mathrm{C}(\mathrm{cP})$ & 3296 & 3538 & 3493 & 3520 & 4194 \\
\hline Viskositas setback (cP) & 1081 & 1164 & 1244 & 1133 & 1482 \\
\hline
\end{tabular}

\section{Karakteristik fisik pati ubi jalar ungu}

Karakteristik fisik pati ubi jalar ungu yang dianalisis dalam penelitian ini yaitu morfologi, sifat birefringence, daya kembang (swelling power), kelarutan dan profil gelatinisasi pati. Pati dalam tanaman mempunyai bentuk granula yang berbeda-beda sesuai dengan varietasnya. Dengan mikroskop, jenis pati dapat dibedakan berdasarkan bentuk, ukuran, letak hilum yang unik dan juga sifat birefringencenya. Granula pati ubi jalar pada umumnya berbentuk poligonal atau hampir berbentuk bulat (Tsakama et al., 2010), juga memiliki hilus sentris. Analisis mikroskopis granula pati dan sifat birefringence pati alami ubi jalar ungu antin-3 (Gambar 1a) menunjukkan bahwa granula pati memiliki bentuk poligonal, juga memperlihatkan birefringence granula pati yang masih baik. Hal ini sama dengan yang dilaporkan oleh Agustinisari (2011) yang menggunakan pati ubi jalar ungu varietas ayamurasaki. Lain halnya dengan pati yang mengalami proses hidrotermal dengan kadar air $30 \%$ dan $50 \%$ serta suhu $55^{\circ} \mathrm{C}$ dan $75^{\circ} \mathrm{C}$, bentuk mikroskopis granula yang terlihat pada Gambar 1 menunjukkan bahwa granula mengalami perubahan bentuk dan kehilangan sebagian sifat birefringencenya. Intensitas birefringence pada pusat granula pati yang mengalami perlakuan hidrotermal tampak berkurang bila dibandingkan pati alaminya. Hal ini diduga karena energi panas disalurkan ke rantai ganda (double helix), atau dengan kata lain terjadi pembentukan kristalit selama proses hidrotermal yang kemungkinan meningkatkan mobilitasnya, sehingga mengakibatkan hilangnya orientasi radial (Chung, 2009). Menurunnya intensitas birefringence dan orientasi radial tampak lebih jelas dan lebih banyak terjadi pada pati hidrotermal dengan perlakuan panas lebih tinggi $\left(75^{\circ} \mathrm{C}\right)$. Hasil penelitian Chung (2009) menunjukkan bahwa perlakuan panas HMT menurunkan birefringence, terutama di pusat granula dan penurunan tersebut lebih tinggi pada pati yang mendapat perlakuan pemanasan $120^{\circ} \mathrm{C}$ dibandingkan pati yang mendapat perlakuan $100^{\circ} \mathrm{C}$.

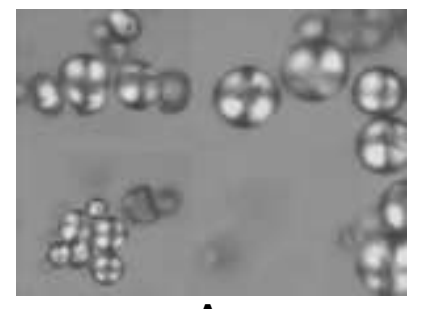

A

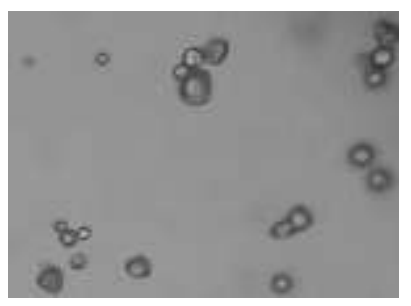

C
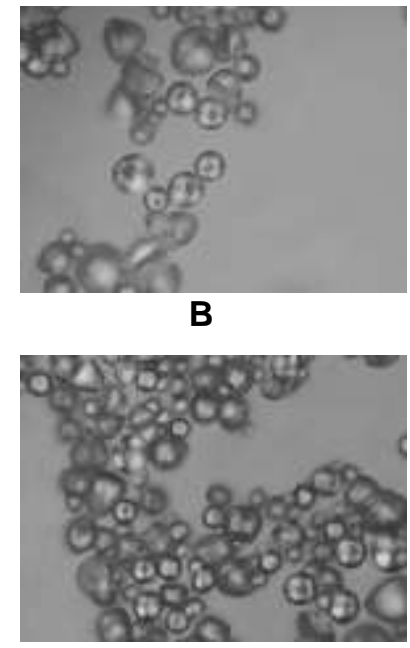

D

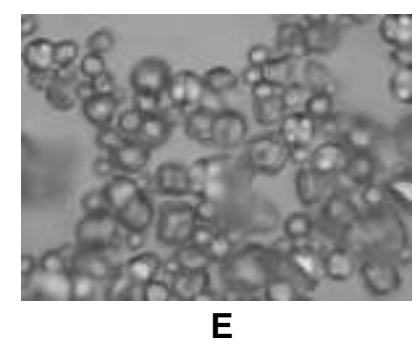

Keterangan: $A=$ Granula pati alami; $B=$ Granula pati hidrotermal $30 \% ; 55^{\circ} \mathrm{C} ; \mathrm{C}=$ Granula pati hidrotermal $30 \% ; 75^{\circ} \mathrm{C}$; D $=$ Granula pati hidrotermal $50 \% ; 55^{\circ} \mathrm{C}$; dan $\mathrm{E}=$ Granula pati hidrotermal $50 \% ; 75^{\circ} \mathrm{C}$

Gambar 1. Struktur granula pati alami dan pati hidrotermal ubi jalar ungu antin-3 di bawah mikroskop polarisasi perbesaran 400x

Pati hidrotermal yang diinkubasi pada suhu $75^{\circ} \mathrm{C}$ memiliki nilai swelling power lebih tinggi daripada pati hidrotermal yang diinkubasi pada suhu $55^{\circ} \mathrm{C}$ seperti yang terlihat pada Gambar 2 . Hal ini terjadi karena amilopektin pada pati hidrotermal suhu $75^{\circ} \mathrm{C}$ jumlahnya lebih banyak dibandingkan 
pati hidrotermal suhu $55^{\circ} \mathrm{C}$, seperti yang terangkum dalam Tabel 1. Amilopektin sangat berperan dalam swelling power. Struktur amilopektin yang banyak mengandung gugus hidrofil menyebabkan amilopektin lebih reaktif mengikat air. Oleh karena itu, amilopektin yang tinggi akan meningkatkan swelling power. Namun perbedaan kadar amilopektin ini tidak berbeda nyata sehingga peningkatan nilai swelling power juga tidak berbeda nyata. Selanjutnya, swelling power pati alami dan pati hidrotermal ubi jalar ungu antin-3 mengalami peningkatan seiring dengan meningkatnya suhu pemanasan. Hal ini sesuai dengan pernyataan Soison et al. (2015) bahwa granula pati mulai mengembang dengan cepat saat mencapai suhu gelatinisasi, dimana suhu gelatinisasi pati alami dan pati hidrotermal ini sekitar 74,55$77,75^{\circ} \mathrm{C}$.

Gambar 3 menunjukkan bahwa kelarutan pati meningkat dengan meningkatnya suhu. Ketika terjadi pemanasan, maka air akan masuk ke daerah amorf dan molekul-molekul penyusunnya, terutama amilosa, akan larut ke media yang ada diluarnya. Pemanasan ini akan meningkatkan energi kinetik air sehingga dapat masuk ke dalam granula pati dan melarutkan komponen-komponen yang ada di dalamnya. Pemanasan yang terus berlangsung akan menyebabkan granula pati pecah sehingga air yang terdapat dalam granula pati dan molekul pati yang terlarut air dengan mudah keluar masuk ke dalam sistem larutan. Molekul pati yang larut dalam air panas (amilosa) akan ikut keluar bersama air tersebut sehingga terjadi leaching amilosa (Oktavia et al., 2013; Alcázar-Alay dan Meireles, 2015). Semakin banyak molekul amilosa yang keluar dari granula pati maka kelarutan semakin tinggi. Oleh karena itu, pati dengan kandungan amilosa yang tinggi pada umumnya memiliki kelarutan yang tinggi pula. Namun, dalam kondisi termodifikasi hidrotermal, granula pati kemungkinan tidak mengalami proses interaksi seperti pada proses gelatinisasi tanpa modifikasi.

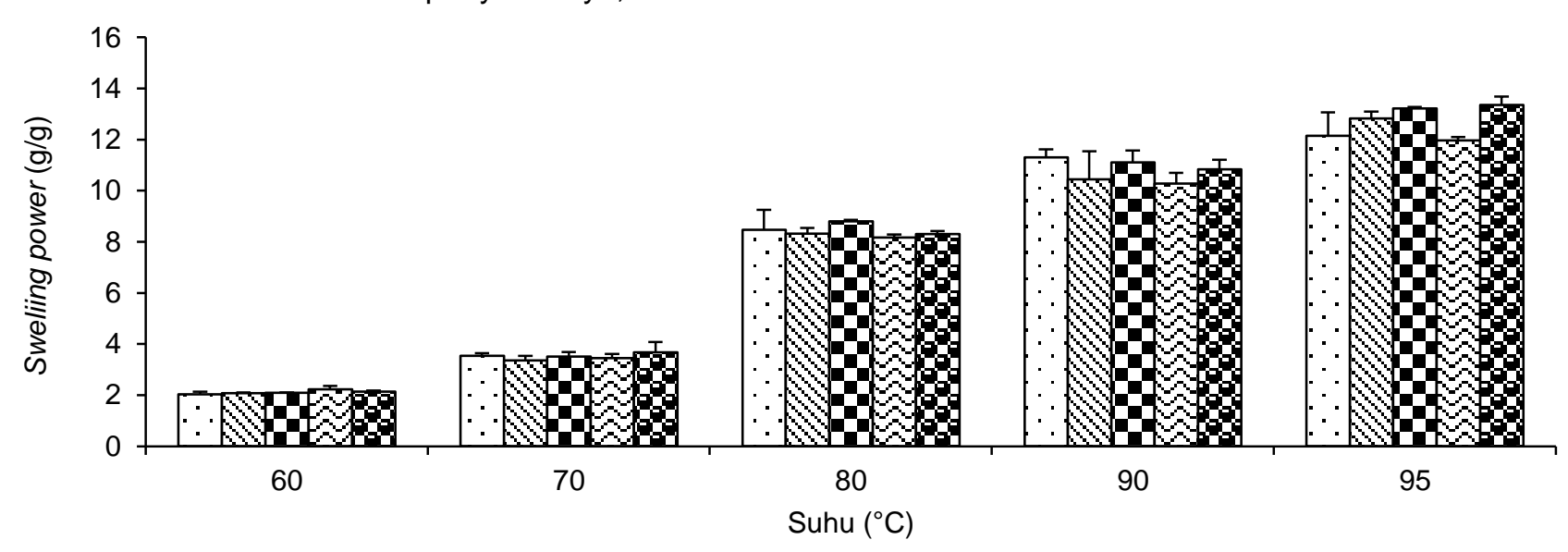

๑Pati Alami $₫ 30 \%, 55^{\circ} \mathrm{C} \bullet 30 \%, 75^{\circ} \mathrm{C} \boxminus 50 \%, 55^{\circ} \mathrm{C} \bullet 50 \%, 75^{\circ} \mathrm{C}$

Gambar 2. Swelling power pati alami dan pati hidrotermal ubi jalar ungu antin-3

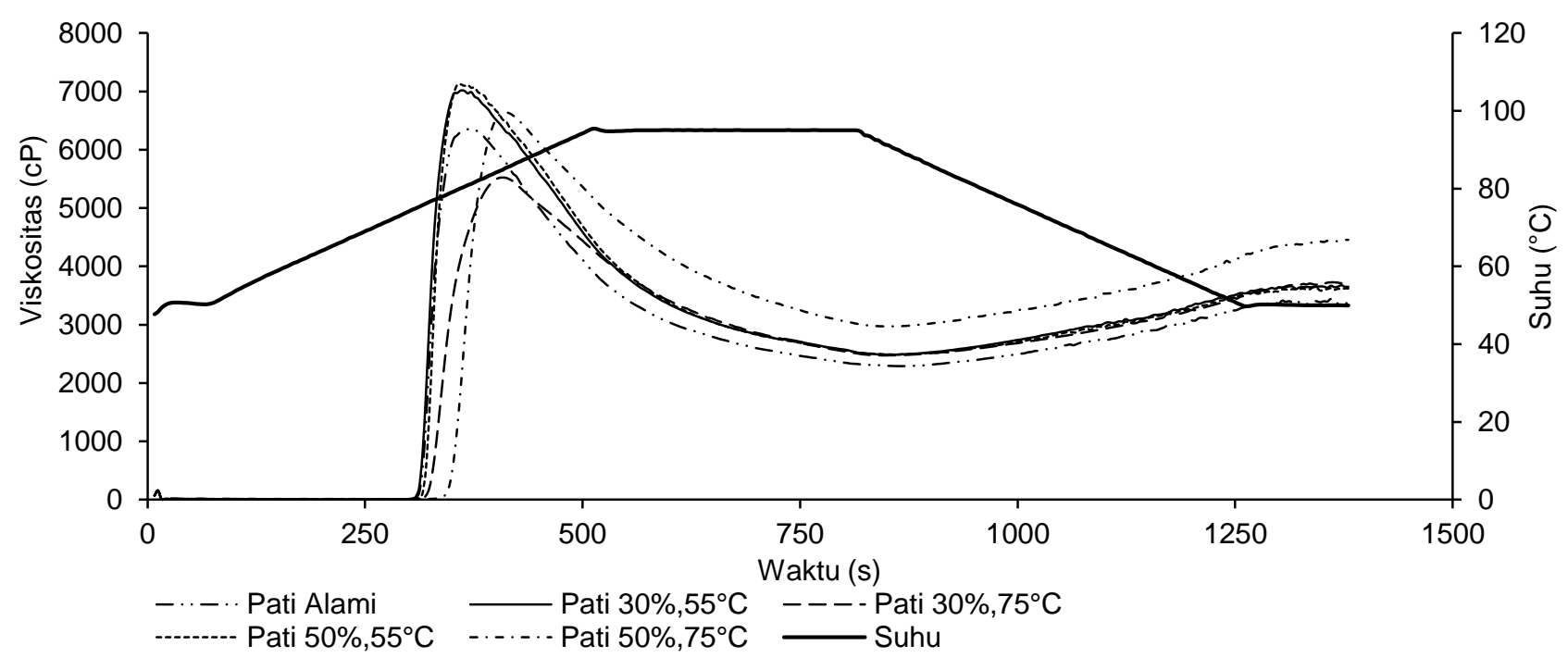

Gambar 3. Kelarutan pati alami dan pati hidrotermal ubi jalar ungu antin-3 
Menurut Zeng et al. (2015), hal ini disebabkan karena pati yang dimodifikasi hidrotermal mengalami perubahan dalam kekuatan ikatan antara unit glukosa dalam pati yang selanjutnya menyebabkan perubahan struktur pati. Perubahan ini kemungkinan menyebabkan pembentukan ikatan hidrogen antara air yang berada di luar granula dengan molekul pati baik amilosa maupun amilopektin menjadi lebih sulit, sehingga kemampuan granula untuk membengkak menjadi terbatas, juga menyebabkan berkurangnya leaching amilosa sehingga kelarutan pati ubi jalar termodifikasi secara hidrotermal menjadi lebih rendah dari kelarutan pati ubi jalar alami.

Berdasarkan profil gelatinisasi pati alami dan pati hidrotermal ubi jalar ungu antin-3 yang diukur menggunakan rapid visco analyzer (RVA) (Gambar 4), pati alami dan pati hidrotermal ubi jalar ungu memiliki profil gelatinisasi pati tipe A berdasarkan pengelompokkan oleh Schoch dan Maywald (1968), yang ditandai dengan nilai viskositas puncak yang cukup tinggi dan viskositas breakdown yang cukup tajam. Dengan demikian, profil gelatinisasi pati ini satu kelompok dengan tapioka serta pati ubi jalar kuning dan putih (Syamsir et al., 2011). Pati alami dan pati hidrotermal mulai mengalami gelatinisasi pada suhu yang cukup tinggi, yaitu antara 74,55$77,75^{\circ} \mathrm{C}$. Suhu gelatinisasi merupakan suatu fenomena sifat fisik pati yang kompleks yang dipengaruhi oleh beberapa faktor, antara lain ukuran molekul amilosa dan amilopektin serta keadaan media pemanasan (Richana et al., 2012). Nilai breakdown merupakan selisih antara nilai viskositas puncak pada suhu $95^{\circ} \mathrm{C}$ dan viskositas pasta panas saat holding pada suhu $95^{\circ} \mathrm{C}$ selama 2 menit (Faridah et al., 2014). Semakin rendah nilai breakdown berarti semakin stabil granula pati tersebut terhadap pengadukan dan pemanasan. Hasil pengamatan pada Tabel 2 menunjukkan nilai breakdown pati hidrotermal yang mendapat perlakuan pemanasan $75^{\circ} \mathrm{C}$ lebih rendah dibandingkan pati hidrotermal dengan perlakuan pemanasan $55^{\circ} \mathrm{C}$. Pati ubi jalar ungu yang memiliki karakteristik stabil selama pengadu- kan dan pemanasan adalah pati hidrotermal dengan kadar air $30 \%$ suhu $75^{\circ} \mathrm{C}$.

Viskositas balik (setback viscosity) merupakan selisih antara nilai viskositas pada suhu $50^{\circ} \mathrm{C}$ dan viskositas saat holdingnya. Selama fase viskositas balik, pendinginan menyebabkan reasosiasi molekul pati yang menghasilkan pembentukan struktur gel dan peningkatan viskositas akibat retrogradasi (Choi et al., 2012). Nilai viskositas balik yang rendah mengindikasikan bahwa pati tersebut memiliki sifat kekentalan yang stabil selama tahap pendinginan, juga kecenderungan mengalami retrogradasi atau sineresis pati yang rendah. Pati hidrotermal yang dipanaskan pada suhu $75^{\circ} \mathrm{C}$ memiliki nilai viskositas balik yang lebih tinggi daripada pati alami dan pati hidrotermal suhu $55^{\circ} \mathrm{C}$. Berarti pati hidrotermal suhu $75^{\circ} \mathrm{C}$ memiliki kecenderungan mengalami retrogradasi dan sineresis lebih tinggi daripada pati alami dan pati hidrotermal suhu $55^{\circ} \mathrm{C}$. Pati yang paling stabil selama pendinginan adalah pati alami karena viskositas baliknya paling rendah.

\section{Karakteristik fungsional pati ubi jalar ungu}

Hasil fraksinasi pati cepat cerna, lambat cerna dan tahan cerna pada pati alami ubi jalar ungu varietas antin-3 berbeda dengan ayamurasaki yang diteliti oleh Agustinisari (2011). Pati ubi jalar ungu ayamurasaki memiliki fraksi pati cepat cerna, lambat cerna dan tahan cerna berturut-turut 16,88; 25,42; $55,09 \%$, sedangkan pada pati ubi jalar ungu antin-3 adalah sekitar 18,$75 ; 28,30 ; 44,06 \%$ seperti yang terlihat pada Tabel 3. Pati alami ubi jalar ungu antin3 memiliki kadar pati lambat cerna yang lebih tinggi daripada pati ubi jalar ungu ayamurasaki. Perlakuan hidrotermal dengan suhu $55^{\circ} \mathrm{C}$ dan $75^{\circ} \mathrm{C}$ serta kadar air $30 \%$ dan $50 \%$ cenderung mengubah struktur pati karena dilakukan dalam waktu yang lama yaitu 24 jam, sehingga persentase fraksi patinya berbeda nyata dengan pati alaminya. Peningkatan kadar pati lambat cerna tertinggi diperoleh dari hasil perlakuan hidrotermal dengan kadar air $50 \%$ dan suhu $75^{\circ} \mathrm{C}$ yaitu sebesar $22 \%$.

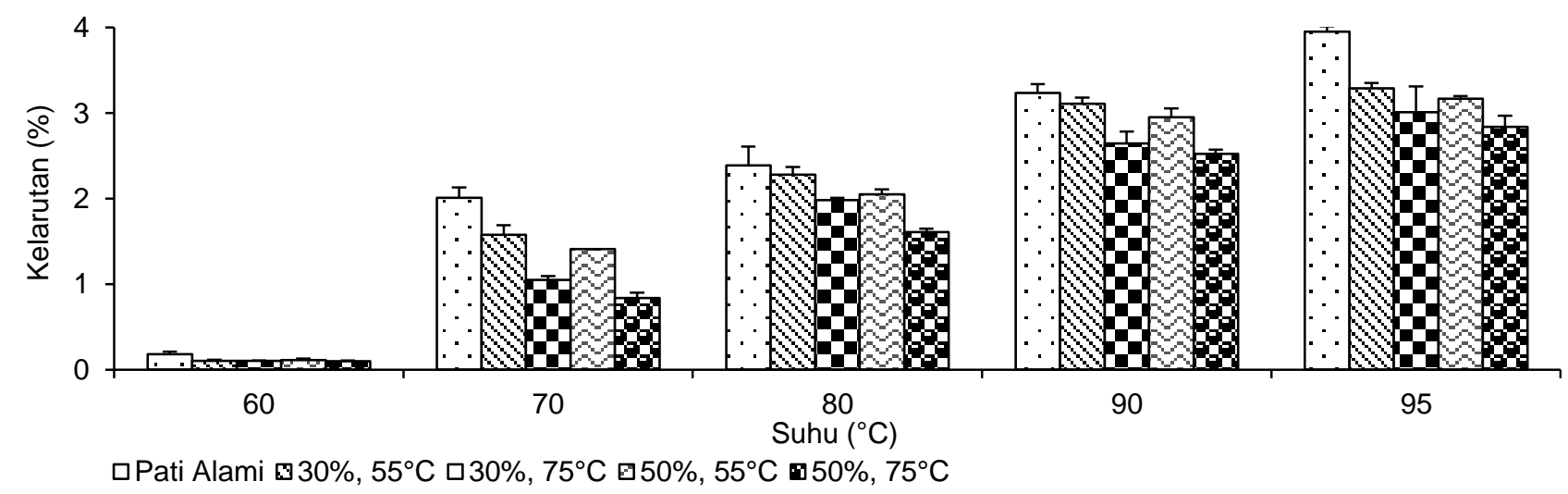

Gambar 4. Profil gelatinisasi pati alami dan pati hidrotermal ubi jalar ungu antin-3 
Tabel 3. Kadar fraksi pati cepat cerna, lambat cerna dan tahan cerna pati alami dan pati hidrotermal ubi jalar ungu antin-3

\begin{tabular}{lccccc}
\hline \multicolumn{1}{c}{ Parameter } & \multirow{2}{*}{ Pati Alami } & $\begin{array}{c}\text { Pati Hidrotermal } \\
30 \%-55^{\circ} \mathrm{C}\end{array}$ & $\begin{array}{c}\text { Pati Hidrotermal } \\
30 \%-75^{\circ} \mathrm{C}\end{array}$ & $\begin{array}{c}\text { Pati Hidrotermal } \\
50 \%-55^{\circ} \mathrm{C}\end{array}$ & $\begin{array}{c}\text { Pati Hidrotermal } \\
50 \%-75^{\circ} \mathrm{C}\end{array}$ \\
\hline Pati cepat cerna (\%) & $18,75 \pm 0,39^{\mathrm{c}}$ & $16,72 \pm 0,28^{\mathrm{ab}}$ & $17,08 \pm 0,57^{\mathrm{b}}$ & $15,57 \pm 0,30^{\mathrm{a}}$ & $17,18 \pm 0,73^{\mathrm{b}}$ \\
Pati lambat cerna (\%) & $28,30 \pm 0,48^{\mathrm{a}}$ & $31,82 \pm 1,95^{\mathrm{b}}$ & $33,25 \pm 0,77^{\mathrm{b}}$ & $32,20 \pm 0,91^{\mathrm{b}}$ & $34,47 \pm 0,52^{\mathrm{b}}$ \\
Pati tahan cerna (\%) & $44,06 \pm 2,73^{\mathrm{b}}$ & $34,74 \pm 5,56^{\mathrm{a}}$ & $37,69 \pm 0,42^{\mathrm{ab}}$ & $36,21 \pm 2,62^{\mathrm{ab}}$ & $35,77 \pm 0,14^{\mathrm{a}}$ \\
\hline
\end{tabular}

Peningkatan kadar pati lambat cerna ini kurang baik dibandingkan hasil yang diperoleh Agustinisari (2011) terhadap pati ubi jalar ungu ayamurasaki yang dimodifikasi secara hidrotermal dengan kadar air $50 \%$ dan suhu $75^{\circ} \mathrm{C}$ yang menghasilkan peningkatan kadar pati lambat cerna sebesar $50 \%$. Kadar pati lambat cerna dari pati hidrotermal ubi jalar ungu antin-3 ini tidak berbeda nyata untuk setiap perlakuan hidrotermal, tetapi berbeda nyata dengan pati alaminya. Hal ini dimungkinkan terjadi disebabkan oleh berbagai faktor antara lain perbedaan luas area permukaan, tipe kristalin, interaksi antar rantai amilosa, kristalinitas serta perubahan daerah amorfous (Agustinisari, 2011). Proses hidrotermal menurunkan kadar fraksi pati tahan cerna dan cenderung meningkatkan kadar fraksi pati lambat cerna. Proses hidrotermal diduga memicu terjadinya pembentukan struktur yang porous yang kemudian memperluas akses hidrolisis enzim (Chung et al., 2009). Beberapa peneliti menduga pembentukan fraksi pati lambat cerna disebabkan oleh terjadinya retrogradasi dan adanya perubahan susunan molekul di daerah amorfous (Wang et al., 2015; Miao et al., 2015). Pada penilitian ini perlakuan hidrotermal pada pati dengan pengkondisian kadar air $50 \%$ dan suhu pemanasan $55^{\circ} \mathrm{C}$ serta terutama suhu $75^{\circ} \mathrm{C}$ menyebabkan sebagian granula pati tergelatinisasi dan beretrogradasi. Selama proses tersebut kemungkinan telah terjadi sejumlah perubahan ditingkat molekular, seperti perubahan struktur kristalit di fase amorfous yang kemudian membentuk struktur granula pati yang sulit dicerna.

\section{KESIMPULAN}

Perlakuan hidrotermal (kadar air 30 dan $50 \%$, suhu 55 dan $75^{\circ} \mathrm{C}$ ) pada pati ubi jalar ungu varietas antin-3 tidak mengubah kadar pati, amilosa, amilopektin, serta bentuk granula dan profil gelatinisasi pati. Sementara daya kembang (swelling power) dan kelarutan mengalami perubahan dan terjadi peningkatan fraksi pati lambat cerna sebesar $22 \%$. Dari hasil analisis karakterisasi fisikokimia dan fungsional, dapat disarankan bahwa pati hidrotermal ubi jalar ungu dapat digunakan sebagai bahan baku olahan pangan yang menggunakan panas tinggi seperti mie, bihun dan flakes.

\section{DAFTAR PUSTAKA}

Agustinisari I, Yasni S, Widowati S. 2011. Peningkatan fraksi pati lambat cerna pada pati ubi jalar ungu melalui proses hidrotermal. Prosiding seminar nasional teknologi inovatif pascapanen pertanian III: 398-404.

Alcázar-Alay SC, Meireles MAA. 2015. Physicochemical properties, modifications and applications of starches from different botanical sources. Food Sci Tech 35: 215-236. DOI: 10.1590/1678 $-457 X .6749$.

Andarwulan N, Kusnandar F, Herawati. 2011. Analisis Pangan. 166-167. Dian Rakyat, Jakarta.

Brumovsky JO, Thompson DB. 2001. Production of boiling-stable granular resistant starch by partial acid hydrolysis and hydrothermal treatments of high-amylose maize starch. Cereal chem 78: 680-689. DOI: 10.1094/CCHEM.2001.78.6.680

Choi I, Han O, Chun J, Kang C, Kim K, Kim Y, Cheong Y, Park T, Choi J, Kim K. 2012. Hydration and pasting properties of oat (Avena sativa) flour. Prev Nutr Food Sci 17: 87-91. DOI: 10. 3746/pnf.2012.17.1.087.

Chung HJ, Liu Q, Hoover R. 2009. Impact of annealing and heat-moisture treatment on rapidly digestible, slowly digestible and resistant starch levels in native and gelatinized corn, pea and lentil starches. Carbohyd Polym 75: 436-447. DOI: 10.1016/j.carbpol.2008.08.006.

Faridah DN, Fardiaz D, Andarwulan N, Sunarti TC. 2014. Karakteristik sifat fisikokimia pati garut (Maranta arundinaceae). Agritech 34: 14-21. DOI: 10.22146/agritech.9517.

Ginting E, Yulifianti R, Yusuf M. 2014. Ubi jalar sebagai bahan diversifikasi pangan lokal. J Pangan 23: 194-207.

Ginting EY, Widodo SA, Rahayuningsih, Yusuf M. 2005. Karakteristik pati beberapa varietas ubi jalar. Penelitian Pertanian Tanaman Pangan 24: 8-18.

Interpares P, Haryadi, Cahyanto MN. 2015. Pengaruh retrogradasi pada pembuatan sohun pati jagung terhadap karakteristik fisikokimia produk dan aktivitas prebiotiknya. Agritech 35: 192199. DOI: $10.22146 /$ agritech.9406. 
Kong X, Kasapis S, Zhu P, Sui Z, Bao J, Corke H. 2016. Physicochemical and structural characteristics of starches from Chinese hull-less barley cultivars. Int J Food Sci Tech 51: 509-518. DOI: $10.1111 /$ ijfs. 12984 .

Luna P, Herawati H, Widowati S, Prianto AB. 2015. Pengaruh kandungan amilosa terhadap karakteristik fisik dan organoleptik nasi instan. J penelitian pascapanen pertanian 12: 1-10. DOI: 10.21082/jpasca.v12n1.2015.1-10.

Miao M, Jiang B, Cui SW, Zhang T, Jin Z. 2015. Slowly digestible starch - a review. Crit Rev Food Sci 55: 1642-1657. DOI: 10.1080/104083 98.2012.704434.

Miao M, Zhang T, Mu W, Jiang B. 2010. Effect of controlled gelatinization in excess water on digestibility of waxy maize starch. Food Chem 119: 41-48. DOI: 10.1016/j.foodchem.2009.05. 035.

Miller GL. 1959. Use of dinitrosalicylic acid reagent for determination of reducing sugar. Anal Chem 31: 426-428. DOI: 10.1021/ac60147a030.

Nazhrah, Julianti E, Masniary L. 2014. Pengaruh proses modifikasi fisik terhadap karakteristik pati dan produksi pati resisten dari empat varietas ubi kayu (Manihot esculenta). J Rekayasa Pangan Pertanian 2: 1-9.

Oktavia AD, Idiawati N, Destiarti L. 2013. Studi awal pemisahan amilosa dan amilopektin pati ubi jalar (Ipomoea batatas Lam) dengan variasi konsentrasi n-butanol. J Kimia Khatulistiwa 2: 153156.

Polnaya FJ, Breemer R, Augustyn GH, Tuhumury HCD. 2015. Karakteristik sifat-sifat fisikokimia pati ubi jalar, ubi kayu, keladi dan sagu. Agrinimal 5: 37-42.

Rahayuningsih SA, Jusuf M, Wahyuni TS. 2012. Perkembangan umbi dan pembentukan pati klon-klon harapan ubijalar kaya B-karotin dan antosianin pada berbagai umur panen. Prosiding Seminar Hasil Penelitian Tanaman Aneka Kacang dan Umbi: 580-589.

Richana N, Ratnaningsih, Haliza W. 2012. Teknologi Pascapanen Jagung. 11. Balai Besar Penelitian dan Pengembangan Pascapanen Pertanian, Bogor.
Schoch TJ, Maywald E. 1968. Preparation and properties of various legume starches. Cereal Chem 45: 564-573.

Shariffa YN, Uthumporn U, Karim AA, Zaibunnisa AH. 2017. Hydrolysis of native and annealed tapioca and sweet potato starches at subgelatinization temperature using a mixture of amylolytic enzymes. Int Food Res J 24: 1925-1933.

Soison B, Jangchud K, Jangchud A, Harnsilawat T, Piyachomkwan K. 2015. Characterization of starch in relation to flesh colors of sweet potato varieties. Int Food Res J 22: 2302-2308.

Syamsir E, Hariyadi P, Fardiaz D, Andarwulan N, Kusnandar F. 2011. Karakterisasi tapioka dari lima varietas ubi kayu (Manihot utilisima Crantz) asal lampung. J Agrotek 5: 93-105.

Syamsir E, Hariyadi P, Fardiaz D, Andarwulan N, Kusnandar F. 2012. Pengaruh proses heatmoisture treatment (HMT) terhadap karakteristik fisikokimia pati. J Teknol Industri Pangan 23: 100-106.

Trinh KS, Lee CJ, Choi SJ, Moon TW. 2012. Hydrothermal treatment of water yam starch in a non-granular state: slowly digestible starch content and structural characteristics. J Food Sci 77: C574-C581. DOI: 10.1111/j.17503841. 2012.02703.x

Tsakama M, Mwangwela AM, Manani TA, Mahayu NM. 2010. Physicochemical and pasting properties of starch extracted from eleven sweetpotato varieties. Afr J Food Sci Tech 1: 090 098.

Wang S, Li C, Copeland L, Niu Q, Wang S. 2015. Starch retrogradation-a comprehensive review. Compr Rev Food Sci F 14: 568-585. DOI: 10.11 11/1541-4337.12143.

Zavareze EDR, Dias ARG. 2011. Impact of heatmoisture treatment and annealing in starches- $A$ review. Carbohyd Polym 83: 317-328. DOI: 10. 1016/j.carbpol.2010.08.064.

Zeng F, Ma F, Kong F, Gao Q, Yu S . 2015. Physicochemical properties and digestibility of hydrothermally treated waxy rice starch. Food Chem 172: 92-98. DOI: 10.1016/j.foodchem.2014.09. 020. 